\title{
リンパ節転移陽性粘膜内胃癌（m 癌）の臨床病理学的検討
}

\author{
県立がんセンター新渇病院外科 \\ 林達彦 梨本 篤 田中 乙雄佐々木壽英
}

1966年より1992年までに当科で手術を施行した粘膜内胃癌 ( $\mathrm{m}$ 癌) 802例のうちリンパ節転移を有す る16例 $(2.0 \%)$ を中心に臨床病理学的特徵の検討を行った. 結果 : (1) n (+) 群は $\mathrm{n}(-)$ 群に比較 し, 組織型は未分化型癌が多く $(\mathrm{p}<0.01)$, 腫場長径が大きく $(\mathrm{p}<0.01)$, 年齢は若い傾向があった $(\mathrm{p}<0.05)$. (2) $\mathrm{n}(+)$ 群のうち肉眼分類は, 隆起型 1 例（I 型）, 混合型 1 例 (IIa + IIc 型), 佇四型 14例（IIc 型 6 例, IIc + III 型 8 例） と陥凹型が多く, 樎山型のうち病巣内消化性漬瘍合併例は 12 例 (85.7\%) と高率であった. (3) n (+) 群のうち, n1 (+) は10例, n2（+）は 5 例, n3 (+) は 1 例 であった. (4)隆起型, 陥凹型とも $2.0 \mathrm{~cm}$ 以下の $\mathrm{m}$ 癌, 占居部位 (C)の $\mathrm{m}$ 癌にはリンパ節転移は 1 例 も認められなかった. (5)70歳以上の高齢者の $\mathrm{m}$ 癌では, $\mathrm{n}(+)$ 群は 1 例のみであった. 今後の高齢者 社会に伴い, 高齢者早期胃癌に対しては社会的適応も考慮し内視鏡的治療法などの合理的な縮小治療 を積極的に取り入れるべきである。

Key words: intramucosal gastric cancer, lymph node metastasis, conservative sugery, social indication

\section{はじめに}

早期胃癌に対するさまざまな縮小手術の合理性に関 する検討が始められて久しく11，それぞれに成果を取 めつつある.機能温存を目的とする癌の縮小手術では, 切除藏器の範囲とリンパ節郭清の範囲が狭くなり, 手 術侵襲がより少さくなる。これにより術後の quality of life（以下，QOL）の低下防止を期待できるが，局 所の根治性と所属りンパ節の郭清に関して, その適応 は厳密であらねばならない。当科では早期胃癌の治療 に際しては, 患者と家族に対する病名告知や術後 QOL, 再発の危険率などの説明を行った後, その症例 にあった縮小治療法（内視鏡的治療を含めて）を選択 し施行している2) 4). 早期胃癌のうち粘膜内癌 (以下, $\mathrm{m}$ 癌) は約 $2 / 3$ であり, 縮小治療の適応となる症例が多 い. そこで単発性 $m$ 癌でリンパ節転移を有する症例を 中心に臨床病理学的事項につき詳細な検討を加えた。

\section{対象と方法}

1966年 1 月より1992年12月までに当科で手術を施行 した胃癌症例は 5,281 例であり, 他臟器重複癌および多 発癌を除いて早期癌は 1,347 例であった. $\mathrm{m}$ 癌は 802 例 で, 16例 (2.0\%) にリンパ節転移を認めた（Fig. 1). これらのうち局所切除などのため $\mathrm{n}$ 因子の不明な 16

$<1994$ 年12月 7 日受理>別刷請求先：林 達彦 干951 新潟市川岸町 2 丁目15-3 県立がんセン タ一新潟病院外科
例を除き単発性 $m$ 癌症例786例を対象とした。病理学 的には病変を全割にて検索し, 特にリンパ節転移陽性 例は今回再検討を加えた。なお, 記載は胃癌取扱い規 約 ${ }^{5} に$ 準じ, 統計学的処理は $\mathrm{t}$-検定, $x^{2}$-検定, logrank 検定によった。

\section{成 績}

1. 背景因子

臨床病理学的諸項目について, 単発性 $\mathrm{m}$ 癌症例をリ ンパ節転移の有無で群別し検討を行った（Table 1). $\mathrm{n}(+)$ 群は16例であり, n(一) 群は770例であった。 $\mathrm{n}(+)$ 群は腫瘍最大径が平均 $5.49 \pm 2.39 \mathrm{~cm}$ で, $\mathrm{n}($ ( ) 群の平均 $2.76 \pm 1.97 \mathrm{~cm}$ に比べ約 2 倍の大きさがあっ た $(\mathrm{p}<0.01)$. 組織型に関しては, $\mathrm{n}(+)$ 群は未分化 型が56.2\%に認められたが, $\mathrm{n}(-)$ 群では逆に分化型 が $75.0 \%$ と大半を占めていた $(\mathrm{p}<0.01)$. 未分化型の $\mathrm{m}$ 癌症例は 200 例で，このうち 9 例 $(4.5 \%)$ に転移を 認めており, 分化型の 581 例中 7 例の転移 $(1.2 \%)$ に 比べ高率であった。年齢は $\mathbf{n}(+)$ 群が平均 $51.3 \pm 13.0$ 歳, $\mathrm{n}(-)$ 群は57.5 11 .6歳で $\mathrm{n}(+)$ 群に若干若い 傾向がみられた $(p<0.05)$.さらに占居部位について みると, $\mathrm{A}$ 領域, $\mathrm{M}$ 領域では $\mathrm{n}(+)$ 群と $\mathrm{n}(-)$ 群の 間に局在による差は認められず，C 領域では 1 例のリ ンパ節転移も認められなかった $(\mathrm{p}<0.01)$. 性別, 肉 眼分類, および ly, v については有意差は認められな かった. 
Fig. 1 Patients (1966. $1 \sim 1992.12$ NIIGATA CANCER CENTER HOSPITAL)

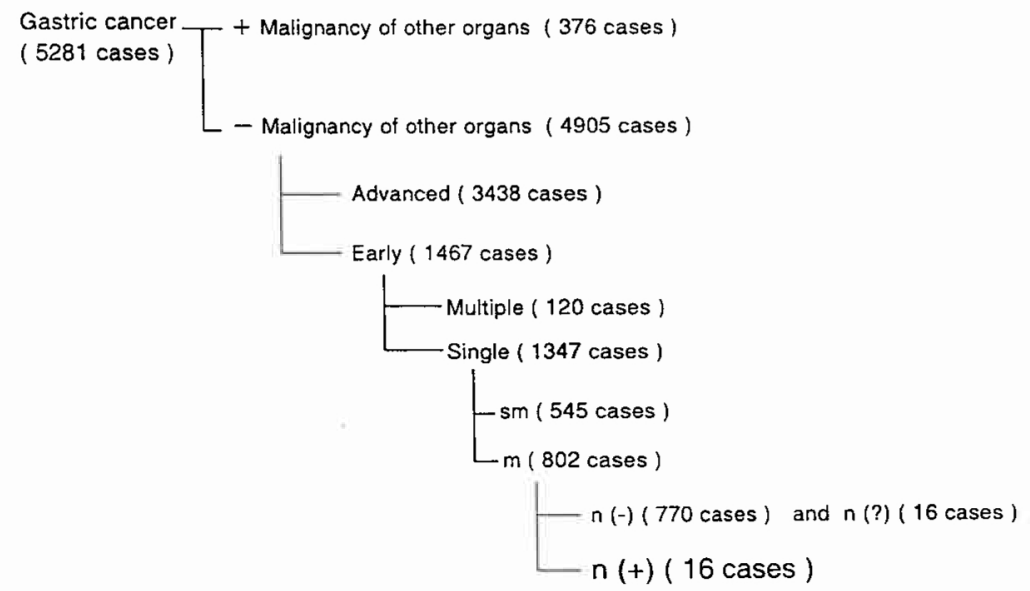

Table 1 Back ground

\begin{tabular}{l|c|c|c}
\hline & $\begin{array}{c}\mathrm{n}(+) \\
\mathrm{n}=16\end{array}$ & $\begin{array}{c}\mathrm{n}(-) \\
\mathrm{n}=770\end{array}$ & (p-value) \\
\hline $\begin{array}{l}\text { Tumor size (cm) } \\
\text { Histological type }\end{array}$ & $5.49 \pm 2.39$ & $2.76 \pm 1.97$ & $\mathrm{p}<0.01$ \\
$\quad$ diff. & $43.8 \%(7)$ & $75.0 \%(577)$ & $\mathrm{p}<0.01$ \\
$\quad$ undiff. & $56.2 \%(9)$ & $25.0 \%(193)$ & \\
Age & $51.31 \pm 13.01$ & $57.52 \pm 11.61$ & $\mathrm{p}<0.05$ \\
Location & & & \\
A & $50.0 \%(8)$ & $50.5 \%(389)$ & \\
M & $43.8 \%(7)$ & $43.4 \%(334)$ & \\
C & $0 \%(0)$ & $5.8 \%(45)$ & $\mathrm{p}<0.01$ \\
MAC & $6.2 \%(1)$ & $0.3 \%(2)$ & \\
\hline Sex & & & NS \\
Gross type & & & NS \\
ly(+) & & & NS \\
v(+) & & & NS \\
\hline
\end{tabular}

\section{2. リンパ節転移群の占居部位別検討}

$\mathrm{C}$ 領域にリンパ節転移例を認められなかったため, $\mathrm{n}$ (+) 群を主占居部位 $\mathrm{A}$ 領域と $\mathrm{M}$ 領域に分けて検討し た(Table 2). MAC 領域の全体癌の 1 例は主占居部位 が M であるため $\mathrm{M}$ 領域に分類した， $\mathrm{A}$ 領域 8 例，M 領域 8 例で, A 領域に 1 例の隆起型（I 型）と 1 例の 混合型（IIa+IIc 型）を認めたが，他の14例（87.5\%） はすべて陥凹型であった。陥凹型のうち病変内に消化 性潰湟合併例（以下，ul (+)) は12例（85.7\%）と高 率であった。 ul(+)のうち ul-II。 3 例, ul-II ul-III $\mathrm{O}_{\mathrm{o}}$ は 3 例, ul-IV $\mathrm{O}$ は 1 例であった。腫瘍最大径は隆 起型, 陥凹型ともに $2 \mathrm{~cm}$ 以下の症例に認めず, 隆起型 は $2.2 \mathrm{~cm}$ 以上であり陥凹型は $2.5 \mathrm{~cm}$ 以上であった。ま
た A 領域の平均腫湯径が $4.79 \mathrm{~cm}$ であるのに対し，M 領域では $6.19 \mathrm{~cm}$ と $\mathrm{M}$ 領域の平均腫㿟径が若干大き い傾向にあった。リンパ節転移個数では，M 領域が 1 症例あたり平均 5.1 個であり, A 領域の1.25個に比べ て高率で, 転移度の高い症例が認められた. A 領域で は 3 例の $\mathrm{n} 2$ 例を認め, $\mathrm{M}$ 領域では 2 例の $\mathrm{n} 2$ 例と 1 例 の $\mathrm{n} 3$ 症例が存在した。これらの腫瘍径はすべて $4.0 \mathrm{~cm}$ 以上であり，肉眼型は宿凹型の潰瘍合併例であった。 組織型をみると，A 領域では 6 例 (75\%) が分化型で あったが，M 領域では逆に 7 例 (87.5\%) が未分化型 であった。年齢は $\mathrm{A}$ 領域, $\mathrm{M}$ 領域で差はなく, 70歳以 上高齢者では 1 例を認めたのみで，80歳以上の症例で 転移例は存在しなかった。

3. 症例提示

1) $M$ 領域一症例 2

64歳の男性で, 第 2 群リンパ節郭清を伴う幽門側胃 要全摘術を施行した。肉眼的には IIc 型, 腫瘍径は $8.5 \times 5.0 \mathrm{~cm}$ で, $\mathrm{H}_{0}, \mathrm{P}_{0}, \mathrm{~S}_{0}, \mathrm{~N}_{1}$, Stage II であった. 組織学的には組織型は sig で, 深達度は $\mathrm{m}$, 右群大彎り ンパ節，幽門下リンパ節，腸間膜根部リンパ節に転移 を認め,第 3 群リンパ節転移陽性であった。術後, $\mathrm{MFC}$ 療法 (Mitomycin C 4mg, Flurouracil 500mg, Cytosine arabinoside 20mg) を10クール施行したが, 術後 4 か月目より腰痛が出現, 肉眼的血尿も加わった. 腹部 CT 検查で第 7 および10胸椎椎体に骨破壊像を認 め, 胃癌骨転移の診断にて放射線療法を開始した。し かし, 血小板減少から DIC, 敗血症を引き起こし術後 約 8 か月で死亡した.

切除標本では病変の範囲が広く, 粘膜表面に変化が 
Table $2 \mathrm{n}(+)$ cases of intramucosal gastric cancer Location (A) $\mathrm{m} \mathrm{n}(+)$ cases

\begin{tabular}{c|c|c|c|l|ll}
\hline Age(y.o.) & Sex & Gross type & Size(mm) & Hist. & & n \\
\hline 1. 60 & M & I & 22 & tub-1 & n1 No. 3 & $1 / 13$ \\
2. 52 & M & IIc & 40 & tub-1 & n1 No. 6 & $1 / 20$ \\
3. 57 & F & IIc + III & 45 & tub-1 & n1 No. 3 & $1 / 21$ \\
4. 58 & F & IIa + IIc & 50 & tub-1 & n1 No. 5 & $1 / 29$ \\
5.74 & F & IIc, (uI-IIs) & 40 & tub-1 & n2 No. 8 a & $2 / 41$ \\
6.33 & M & IIc + III & 60 & tub-2 & n2 No. 7 & $1 / 35$ \\
7. 37 & F & IIc + III & 95 & por & n2 No. 1, No. 9 & $2 / 35$ \\
8.38 & M & IIc & 31 & muc & n1 No. 6 & $1 / 29$ \\
\hline
\end{tabular}

Location $(\mathrm{M}) \mathrm{m} n(+)$ cases

\begin{tabular}{c|c|c|c|l|lr}
\hline Age(y.o.) & Sex & Gross type & Size $(\mathrm{mm})$ & Hist. & \multicolumn{1}{|c}{ n } \\
\hline 1. 35 & M & IIc +III & 60 & tub-1 & n1 No. 3 & $1 / 15$ \\
2. 64 & M & IIc, (uI-IIs) & 85 & sig & n3 No. 4d, No. 6, No. 14 & $8 / 34$ \\
3. 36 & F & IIc, (uI-IIs) & 60 & sig & n1 No. 4d & $1 / 26$ \\
4. 41 & F & IIc+III & 40 & por & n2 No. 3, No. 6, No. 8a, No. 9 & $11 / 55$ \\
5. 52 & F & IIc +III & 55 & por & n2 No. 2, No. 3, No. 4d & $3 / 18$ \\
6. 61 & M & IIc +III & 25 & por & n1 No. 3 & $4 / 40$ \\
7. 68 & F & IIc +III & 105 & por & n1 No. 3, No. 4d, No. 4sb & $13 / 60$ \\
8. 55 & F & IIc, (uI-IIs) & 65 & por & n1 No. 1, No. 3 & $3 / 36$ \\
\hline
\end{tabular}

Fig. 2 Resected specimen revealed a wide and illdefined depressed lesion with ul-II scar in the anterior wall and posterior wall of the middle body.

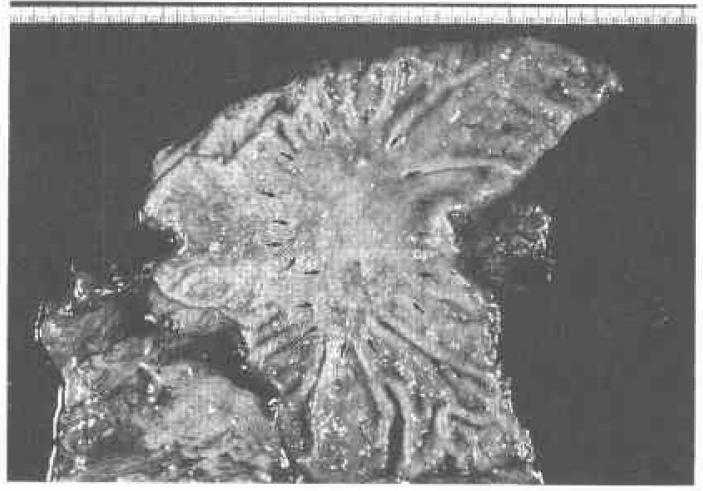

少ないため, 正常粘膜との境界が判別しにくい病変で あった（Fig. 2).

\section{2) $M$ 領域一症例 6}

61歳の男性で第 2 群リンパ節郭清を伴う幽門側胃亜 全摘術を施行した. 肉眼的には腫瘍径が $3.5 \times 2.5 \mathrm{~cm}$ で, 肉眼型は IIc+III 型であった. 組織学的には腫湯径 は2.5cm, 組織型は por, 深達度は $\mathrm{m}$, 小彎リンパ節に 4 個の転移を認めた。比較的小さな病変であるが, 多
Fig. 3 Resected specimen revealed an intramucosal cancer type IIc+III measuring 3.5 $\mathrm{cm} \times 2.5 \mathrm{~cm}$ in size in the anterior wall of the upper body.

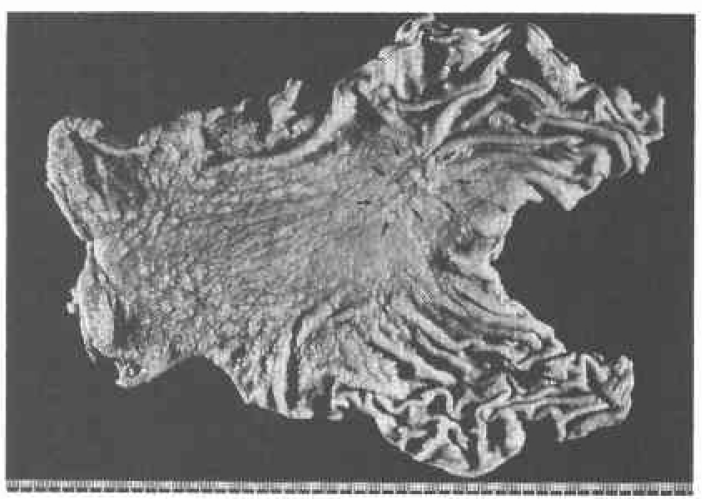

くのリンパ節転移を認めた症例であり提示した。

切除標本では ul-II scar を伴う島状粘膜のある陥凹 性病変であった (Fig. 3).

4. 肉眼判定と組織判定によるリンパ節転移の比較 検討

リンパ節転移の肉眼判定と組織学的診断の比較検討 を行った (Table 3). m 癌全体では過小評価は11/ $786(1.4 \%)$, 正診は714/786(90.8\%), 過大評価は61/ 
Table 3 Lymph node metastasis

$-\mathrm{N}$ vs $\mathrm{n}-$

$\mathrm{m}: 786 \mathrm{cases}$

\begin{tabular}{l|c|c|c|c}
\hline & $\mathrm{N}(-)$ & $\mathrm{N} 1(+)$ & $\mathrm{N} 2(+)$ & $\mathrm{N} 3,4(+)$ \\
\hline $\mathrm{n} 0$ & 709 & 52 & 9 & 0 \\
\hline $\mathrm{n} 1(+)$ & 7 & 3 & 0 & 0 \\
\hline $\mathrm{n} 2(+)$ & 1 & 2 & 2 & 0 \\
\hline $\mathrm{n} 3(+)$ & 0 & 1 & 0 & 0 \\
\hline $\mathrm{n} 4(+)$ & 0 & 0 & 0 & 0 \\
\hline
\end{tabular}

$\mathrm{N}<\mathrm{n} \quad 1$ cases $1.4 \%$

$\mathrm{N}=\mathrm{n} \quad 714$ cases $90.8 \% \quad \mathrm{n}(+): \mathrm{N}<\mathrm{n} \quad 11 / 16 \quad(68.8 \%)$

$\mathrm{N}>\mathrm{n}$ 61cases $7.8 \%$

Table 4 Lymph node metastasis of intramucosal gastric cancer

$-<70$ y.o. vs 70 y.o. $\geqq-$

$<70$ y.o. $\quad 70$ y.o. $\geqq$

\begin{tabular}{rr|r|r|r}
\hline \multirow{2}{*}{ m cancer } & $\mathrm{n}(-)$ & $659(97.8 \%)$ & $111(99.1 \%)$ & \\
& $\mathrm{n}(+)$ & $15(2.2 \%)$ & $1(0.9 \%)$ & \\
\hline & & $674(100 \%)$ & $112(100 \%)$ & 786 \\
\hline
\end{tabular}

786 (7.8\%)であった．正診率が高率であるのはn(一) 群が多い結果と考えられた。しかし，n(+)群に限つ て検討すると過小評価が11/16 (68.8\%) と高率であっ た. 肉眼判定があくまで補助的な診断であり，微小転 移に対する術中判定が困難であることが示された。

5. 高齢者のリンパ節転移の検討

$\mathrm{n}$ 因子の明らかな $\mathrm{m}$ 癌症例 (786例) を70歳以上と70 歳未満の 2 群に分けてリンパ節転移率を検討した (Table 4).70歳末満が15/674（2.2\%）であるのに対 し，70歳以上では $1 / 112(0.89 \%)$ と低率であった。胃 癌全症例 $(4,655$ 例), および sm 癌症例 (541例) でも 同様の検討を行ったが，2つの群においてリンパ節転 移率に差はみられなかった. 70 歳以上の $\mathrm{m}$ 癌の遠隔成 績をみると（Fig. 4)，他病死を含んだ 5 年生存率は $85.1 \%$ であるのに対し，他病死を除いた 5 年生存率は $96.9 \%$ であり, 他病死が多く存在していた $(\mathrm{p}<0.01)$.

6. $\mathrm{m}$ 癌リンパ節転移率の年代別変遷 $\mathrm{m}$ 癌におけるリンパ節転移率の年代別変遷を示し た(Fig. 5).1960年代後半の転移率が，4.3\%であるの に対し，1990年代前半には1.4\%と低下している. 診断 技術の向上に伴い, 上り腫瘍長径の小さい $\mathrm{m}$ 癌が早期 発見されて手術を施行されるようになったため，転移 率は年々低下傾向にあると考光られた。
Fig. 4 Survival rate of intramucosal gastric can cer patients over 70y.o.

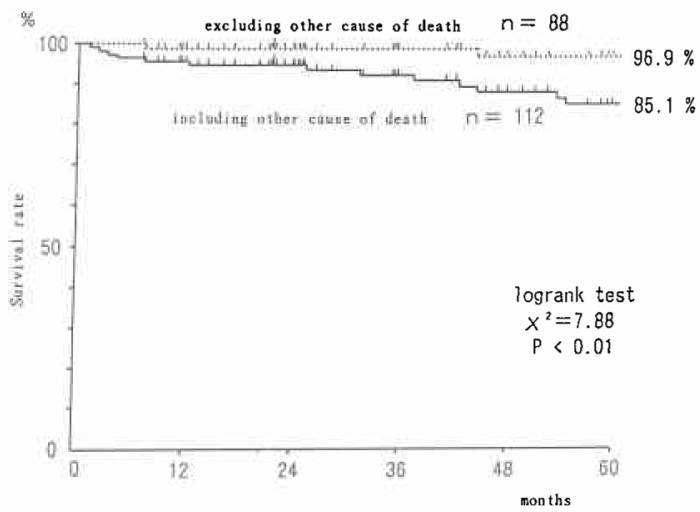

Fig. 5 Trends of incidence of metastasis of intramucosal gastric cancer

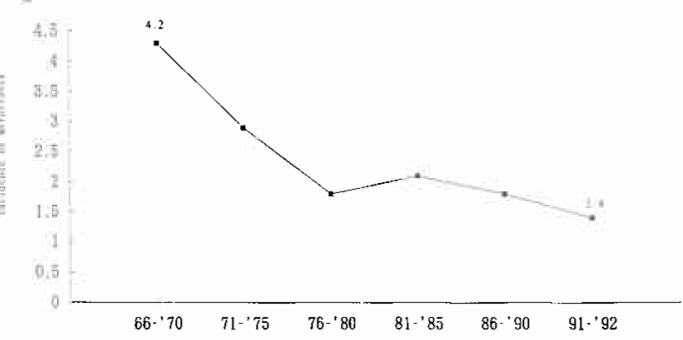

\section{考察}

縮小治療の普及に伴い, $\mathrm{m}$ 癌, $\mathrm{n}(+)$ 群の報告は多 いが，背景因子である $\mathrm{n}($ (一)群と比較検討されたもの は少ない，今回我々は $\mathrm{m}$ 癌， $\mathrm{n}(+)$ 症例の特徵をとら える目的で, $\mathrm{n}(+)$ 群と $\mathrm{n}($ (一) 群の比較を行った.

腫瘍最大径, 肉眼型についてみると $\mathrm{n}(+)$ 群は平均 $5.49 \mathrm{~cm}$ でn (一) 群の約 2 倍と大きく, 隆起型, 陥凹 型ともに $2 \mathrm{~cm}$ 以下の症例に転移は認めなかった。しか し IIc 型では腫場長径 $2 \mathrm{~cm}$ 以下でも転移例を認める報 告例が多く6) 9), とくに ul(十)では注意が必要である. 北岡ら”の報告では, $\mathrm{n}(+)$ の $\mathrm{m}$ 癌, 12例すべてが $\mathrm{ul}$ （十）であり，岩下ら》の報告でも，陥凹型 $\mathrm{m}$ 癌の $\mathrm{n}$ (十)，7例すべてがul（十）である. 我々の検討でも 陥凹型 $\mathrm{n}(+)$ の $\mathrm{m}$ 癌では ul (+) を $85.7 \%$ と多く認 めている。また $\mathrm{m}$ 癌の陥型を ul $(+)$ と ul (一) に 分けてみると, ul (一) のリンパ節転移率は2/ $323(0.62 \%)$ であるが, ul (+) では $12 / 172(7.0 \%)$ と高率であった。さらに n2以上のリンパ節転移を有す る $\mathrm{m}$ 癌は 6 例存在していたが,すべて $4.0 \mathrm{~cm}$ 以上の陷 
凹型で, ul (十) であった。

組織型では, 未分化型が $\mathrm{n}(-)$ 群に比較し多く認め られ $(\mathrm{p}<0.01)$ ，他の報告例(6)7) と一致した。末分化型 の転移率は $4.0 \sim 5.0 \%$, 分化型では1.2〜 $1.8 \%$ 程度と 考えられる。

また年齢は若干若い傾向があり（ $\mathrm{p}<0.05 ）, 70$ 歳以 上の高龄者で 1 例を認めたのみで, 80 歳以上に転移例 は存在しなかった.70歳以上の $\mathrm{m}$ 癌の遠隔成績をみる と, 他病死が多く存在することが明らかである. 加え て年々 $\mathrm{m}$ 癌症例のリンパ節転移率は低下している. よって高齢者の $\mathrm{m}$ 癌では, 症例に応じて社会的な適応 も考慮した治療方法を選択し, 可能な限り機能温存を 図るべきであると考える。

当科では，(1) 最大径 $2 \mathrm{~cm}$ 以下の隆起型拉よび IIb 型 $\mathrm{m}$ 癌, (2) 最大径 $1 \mathrm{~cm}$ 以下の $\mathrm{ul}$ (-) IIc 型 $\mathrm{m}$ 癌を 内視鏡治療の適応としてきた。しかし，リンパ節転移， 病変範井や大きさの確定, 病変部位, さらには術者の 熟練度などの問題から, 内視鏡治療で完全を期すには, 最大径 $1 \mathrm{~cm}$ 以下の隆起型 $\mathrm{m}$ 癌が最もよい適応である と考える. また70歳以上の高齢者早期胃癌では, 患者 の QOL を考慮しやや適応を拡大し内視鏡的治療を試 みる価值があると思われる、ただし，高齢者には多発 病変が多いことを認識し，1つの病変のみならず胃全 体の厳重な経過観察が必要である。

また，外科的縮小手術法として大網を温存した第 1 群リンパ節郭清を伴う胃切除術, 幽門温存胃切除術, 外科的粘膜下切除術を, その症例に応じて選択し施行 している4).

今回の検討では第 2 群以上のリンパ節転移を有する $\mathrm{m}$ 癌は 6 例で，すべて最大径が $4 \mathrm{~cm}$ 以上であった. 安 全域を考えて, 最大径 $2 \mathrm{~cm}$ 以下の $\mathrm{m}$ 癌を対象に大網を 温存した第 1 群リンパ節郭清を伴う胃切除術を施行し ている.
占居部位 $\mathrm{M}$ 領域の $\mathrm{m}$ 癌では 8 例にリンパ節転移を 認めているが，幽門上リンパ節，肝十二指腸間膜内リ ンパ節，膵頭後部リンパ節には転移は認めなかった。 すなおち, $\mathrm{M}$ 領域の多くの症例に幽門温存胃切除術の 適応があると考えられる。

占居部位が $\mathrm{C}$ 領域の $\mathrm{m}$ 癌では 1 例の転移も認めら れなかったが, 文献的には若干の転移例を認めてお $\eta^{4) 99}$, 安全域を考慮し, C 領域で最大径 $3 \mathrm{~cm}$ 以下の隆 起型 $\mathrm{m}$ 癌, 最大径 $1 \mathrm{~cm}$ 以下の陥山型 $\mathrm{m}$ 癌は外科的粘 膜下切除術の適応と考えている.

本論文の要旨は, 第36回日本消化器内視鏡学会甲信越地 方会, および第63回胃癌研究会で発表した。

\section{文献}

1）北岡久三, 吉川謙蔵, 鈴木雅雄ほか：早期胃癌の所 属リンパ節温存手術に関する検討. 日癌治療会誌 $18: 969-978,1983$

2）梨本 篤, 佐々木壽英： $m, s m$ 早期胃癌に対する 局所治療. 日消外会誌 26:2527-2531, 1993

3）梨本 篤, 田中乙雄: 外科医の立場からみた早期 胃癌に対する内視鏡治療について. Endosc Forum Digest Dis 5 : 159-165，1989

4）梨本 篤：早期胃癌に対する外科的縮小手術. Endosc Forum Digest Dis 10:23-31, 1994

5）胃癌研究編：胃癌取扱い規約. 第11版. 金原出版, 東京, 1985

6) 鈴木博孝, 喜多村陽一, 笹川 剛ほか：早期胃癌に 対するリンパ節郭清の合理化に関する検討. 外科 治療 $64: 311-320,1991$

7) 岩下明徳, 山田 豊, 有田正秀ほか：病理学的にみ た早期胃癌内視鏡的切除の適応条件. 胃と腸 $26: 265-274,1991$

8）笹子三津留, 木下 平, 丸山圭一ほか: 早期胃癌に 対する局所切除. 日消外会誌 $23: 2191-2195$, 1990

9）岡島邦雄, 山田眞一, 磯崎博司ほか: 早期胃癌内視 鏡的切除の評価. 胃と腸 $26: 371-377,1991$

\section{A Clicopathological Study of Lymph Node Positive Intra Mucosal Gastric Cancer}

Tatsuhiko Hayashi, Atsushi Nashimoto, Otsuo Tanaka and Juei Sasaki Division of Surgery, Niigata Cancer Center Hospital

Sixteen cases of lymph node-positive $[\mathrm{n}(+)]$ single intramucosal gastric cancer, resected in Niigata Cancer Center Hospital from 1966 to 1992, were analyzed in comparison with 770 lymph node-negative $[n(-)]$ cases. The results were as follows. (1) The $n(+)$ cases showed a higher frequency of undifferentiated type in histology, were larger in size and were younger than the $n(-)$ cases. (2) All $n(+)$ cases were depressed type ( 6 cases of type IIc and 8 cases of type IIc + III) except for 2 cases ( 1 case of type I and 1 case of type IIa + IIc). Twelve cases of the depressed type ( $85.7 \%$ ) were accompanied with peptic ulcer 
in the lesion. (3) The $n(+)$ cases included 10 cases of $n 1(+), 5$ cases of $n 2(+)$ and 1 case of $n 3(+)$. (4) No lymph node metastasis was seen in the elevated type of less than $2.0 \mathrm{~cm}$ in diameter, the depressed type of less than $2.0 \mathrm{~cm}$ in diameter, or any type located in the upper third portion. (5) There was only 1 patient over 70 years of age. From now on, as the number of aged patients increases, we should perform rational treatment for aged early gastric cancer patients considering the social indication.

Reprint requests: Tatsuhiko Hayashi Division of Surgery, Niigata Cancer Center Hospital 2-15-3 Kawagishicho, Niigata City, 951 JAPAN 